\section{Merkel cell distribution in the human eyelid}

\author{
C.A. May, I. Osterland \\ Department of Anatomy, Dresden \\ University of Technology, Germany
}

\begin{abstract}
Although Merkel cell carcinoma of the eyelid is reported frequently in the literature, only limited information exists about the distribution of Merkel cells in this tissue. Therefore, serial sections of 18 human cadaver eyelids (donors ages ranging between 63 and 97 years) were stained for cytokeratin 20 in various planes. The overall appearance of Merkel cells in these samples was low and mainly located in the outer root layer of the cilia hair follicles. Merkel cells were more frequent in the middle, and almost not detectable at the nasal and temporal edges. The localization is in accordance with that of Merkel cell carcinoma, but concerning the scarce appearance within this adulthood group, a specific physiological role of these cells in the eyelid is difficult to establish.
\end{abstract}

\section{Introduction}

In the humans, Merkel cells show great variations in their density and distribution between different cutaneous and mucosal regions. ${ }^{1}$ Merkel cells are supposed to mediate mechanosensitive properties, revealing small receptive fields with slow adaptation and tonic response. ${ }^{2}$ In addition, paracrine functions are suggested due to the electron microscopic appearance of dense core vesicles and due to their histochemical characterization. ${ }^{3}$

The presence of Merkel cells in the human eyelid was studied in only one publication: ${ }^{4}$ they used electron microscopy of two donor tissue samples (donors age 14 and 38 years), but they did not specify the location of their samples within the eyelid neither did they estimate any frequency of appearance. Merkel cell carcinoma, which has been described frequently in the eyelid, is believed to be derived from Merkel cells or from stem cells, and recently polyomavirus has been proposed in the induction of this neoplasm. ${ }^{5,6}$ Nowadays, a specific cytokeratin (CK 20) is known to selectively stain Merkel cells at all epithelial locations. ${ }^{7}$ The present work describes the distribution of Merkel cells in the upper and lower eyelid and anterior eye surface of old human donors, the age group with the highest incidence of Merkel cell carcinoma.

\section{Materials and Methods}

The upper and lower eyelids, conjunctiva and cornea of five human donors and the upper eyelid of additional 13 human donors were observed post-mortem (Table 1). All donors were part of the donor program of the Department of Anatomy in Dresden and had given a written consent that their body might be used for educational and scientific purposes after death. All procedures were in accordance with the ethical standards of the institutional and national committees responsible for human experimentation. The bodies were fixed in a solution of $10 \%$ formalin for several months. The lids were dissected in six portions with equal length and rinsed in phosphate buffered saline (PBS). Samples of each portion were embedded in paraffin, additional sections of selected portions were cryo-sectioned. Sections (10-20 $\mu \mathrm{m}$ thick) were mounted on glass slides and prepared for immunohistochemistry. The sections were incubated with pronase (diluted 1:20 in PBS; DakoCytomation) for $15 \mathrm{~min}$ at $37^{\circ} \mathrm{C}$ and then rinsed with distilled water. Incubation with mouse-anti CK20 antibody (diluted 1:20; DakoCytomation) was performed overnight at $4^{\circ} \mathrm{C}$. After rinsing, the sections were either prepared for fluorescence microscopy using an appropriate Cy3-conjugated secondary antibody (diluted 1:300; Dianova) or visualized using a Vectastain Elite $\mathrm{ABC}$ Kit (Vector, Burlingame, CA, USA) for light microscopy.

\section{Results}

Serial sections of various planes through the upper and lower eyelid revealed a highly specific distribution and localization of CK 20 positive Merkel cells. The overall appearance was low and only occasionally Merkel cells were detected in single sections (Figure 1; Table 1): in 4 out of the 18 donors no Merkel cells were seen in the area studied, 11 donors showed low numbers of Merkel cells (up to 10 cells in the area studied), and only 3 donors showed 15 or more Merkel cells. There was no correlation of the cell number with age, sex, or post-mortem time. Most donors showed similar counts of the right and left side with the exception of two donors (a 87-year-old female and a 91-year-old male). Most positive cells were located in the outer root layer of the cilia hair follicles (often arranged in groups; all 14 cases with positive Merkel cells), and to a lesser degree associated with the small hairs of the cornified epithelium (4 out of 14 cases) or simply in the cornified epithelium (dermal Merkel cells) at the lid margin ( 2 out of 14
Correspondence: Prof. Dr. Christian Albrecht May, Anatomisches Institut, Technische Universität Dresden, Fetscherstr. 74, 01307 Dresden, Germany. Tel. +49.351.4586105. E-mail: Albrecht.May@mailbox.tu-dresden.de

Contributions: CAM, concept and design, data acquisition and interpretation, drafting the article; article drafting and final approval; IO, data acquisition and interpretation, article drafting and final approval.

Conflict of interests: the authors declare no competing interests.

Key words: eyelid, human, cytokeratin 20, Merkel cell.

Received for publication: 28 June 2013. Accepted for publication: 3 September 2013.

This work is licensed under a Creative Commons Attribution NonCommercial 3.0 License (CC BYNC 3.0).

(0) Copyright C.A. May and I. Osterland, 2013 Licensee PAGEPress, Italy

European Journal of Histochemistry 2013; 57:e33 doi:10.4081/ejh.2013.e33

cases; Table 1). Numerous sections through all portions revealed an accumulation of positive Merkel cells in the central portions of the upper and lower eyelid (Figure 2). No CK 20 positive Merkel cells were detected in the conjuctival and corneal epithelium.

The positive stained Merkel cells appeared as roundish or oval cells with a size similar as the surrounding epithelial cells $(9-16 \mu \mathrm{m}$; inset of Figure 1A). The relation between nucleus and cytoplasm was towards the nucleus. CK 20 stained completely the cytoplasm leaving the nucleus unstained.

\section{Discussion}

Although the number of Merkel cells showed a high inter-individual variety, there was no obvious influence of sex, age or post-mortem time in the samples studied. The lack of any positive Merkel cells in 4 cases is probably due to the sample size of the specific portion. Other portions of these donors revealed single positive Merkel cells and there was no case showing absolutely no positive cells. It remains to be determined if the long-lasting fixation could influence the staining behaviour of individual cases.

The appearance of Merkel cells in the eyelids was rare and the cells were mainly located in the cilia outer root layer of the central portions. The eyelids are considered to react very 
sensitive towards touch and pressure, and in this respect the low number and specific location of Merkel cells observed in this study was rather surprising. To discuss this fact in more detail, three questions were phrased: i) Why are there no Merkel cells in the conjunctiva and corneal epithelium? In general, Merkel cells are known to be present in the mucosa. ${ }^{1,3}$ For the corneal epithelium, the high and specific turnover from limbal to central might serve as a sufficient argument. ${ }^{8}$ The corneal epithelium is specific in keeping no stable basal layer but a constant shift allowing only free nerve endings to sprout and directly translate fine sensitivity. This is similar to the hair root where Merkel cells only appear in the permanent and not in the cyclic part of the epithelium. ${ }^{3}$ The difference of the mentioned epithelia to those containing Merkel cells is not the fact of cell migration per se (this occurs in all epithelia from basal to superficial), but the lack of a stable basal cell layer containing stem cells. The epithelium of the conjunctiva is mainly in contact with itself due to constant eyelid movement. This might constitute a situation which can sufficiently function without Merkel cell specific sensation (slow adaptive and tonic in response). ii) Why are almost no Merkel cells in the cornified outer epithelium of the eyelids? The distribution of Merkel cells in the skin of the face shows local differences: high numbers are reported in the lips, lower numbers in the nose, earlobes and cheek, and poor numbers in the scalp and forehead. ${ }^{1}$ In contrast to the lips and nose, the number of Merkel cells in the eyelids is comparable to the forehead. Functional implications for this differentiated distribution of Merkel cells within the face are unknown. iii) Could the appearance of Merkel cells in the root of the cilia have some functional significance? The localization of the cilia-associated Merkel cells is similar to that described for the hair of the head, ${ }^{9}$ however their number did not reach those described

Table 1. Data of the donors and number of Merkel cells in eight consecutive sections (representing a total thickness of $0.1 \mathrm{~mm}$ ) of a middle portion of the upper eye lid.

\begin{tabular}{|c|c|c|c|}
\hline Donor age (years) & Donor sex & Post-mortem time (days) & Number of Merkel cells* \\
\hline 63 & $\mathrm{M}$ & 2 & $5 / 0 / 0$ \\
\hline 72 & M & 3 & $4 / 2 / 0$ \\
\hline 74 & $\mathrm{~F}$ & 1 & $\begin{array}{l}8 / 3 / 0 \\
9 / 0 / 0\end{array}$ \\
\hline 75 & M & 4 & $\begin{array}{l}0 / 0 / 0 \\
0 / 0 / 0\end{array}$ \\
\hline 77 & $\mathrm{~F}$ & 3 & $\begin{array}{l}0 / 0 / 0 \\
0 / 0 / 0\end{array}$ \\
\hline 79 & $\mathrm{~F}$ & 1 & $\begin{array}{l}0 / 0 / 0 \\
0 / 0 / 0\end{array}$ \\
\hline 79 & M & 8 & $9 / 0 / 1$ \\
\hline 81 & $\mathrm{~F}$ & 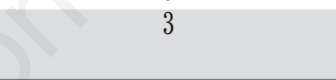 & $\begin{array}{l}2 / 0 / 0 \\
0 / 0 / 0\end{array}$ \\
\hline 84 & $\mathrm{~F}$ & 1 & $\begin{array}{l}1 / 0 / 0 \\
2 / 0 / 0\end{array}$ \\
\hline 87 & $\mathrm{~F}$ & 1 & $\begin{array}{c}21 / 0 / 2 \\
4 / 0 / 0\end{array}$ \\
\hline 87 & $\mathrm{~F}$ & 2 & $\begin{array}{l}3 / 0 / 0 \\
1 / 0 / 0\end{array}$ \\
\hline 88 & M & 2 & $\begin{array}{l}0 / 0 / 0 \\
1 / 0 / 0\end{array}$ \\
\hline 88 & $\mathrm{~F}$ & 1 & $\begin{array}{l}2 / 0 / 0 \\
0 / 0 / 0\end{array}$ \\
\hline 89 & M & 2 & $\begin{array}{l}0 / 0 / 0 \\
0 / 0 / 0\end{array}$ \\
\hline 91 & M & 1 & $\begin{array}{c}11 / 4 / 0 \\
3 / 4 / 0\end{array}$ \\
\hline 91 & $\mathrm{~F}$ & 1 & $1 / 0 / 0$ \\
\hline 94 & M & 1 & $2 / 0 / 0$ \\
\hline 97 & $\mathrm{~F}$ & 2 & $\begin{array}{l}17 / 13 / 0 \\
17 / 10 / 0\end{array}$ \\
\hline
\end{tabular}

*The numbers are arranged in triplets due to their location: outer root layer of the ciliae hair follicles/small hairs of the cornified epithelium/cornified epithelium at the lid margin; two lines indicate left and right lid.

in the literature. ${ }^{10}$ Since Merkel cells at this location are not constantly innervated, ${ }^{11}$ their mechanosensitive function is questionable.

If we still assume a classic Merkel cell function for the cells described in this paper, it could be related to the lid closure mechanism and the regulation of the muscle tone in relation to the contact of the middle portion of the eyelid. ${ }^{12}$ In this respect Merkel cells might have some fine tuning influence.

The location of Merkel cells in the eyelid described in this study was in accordance with

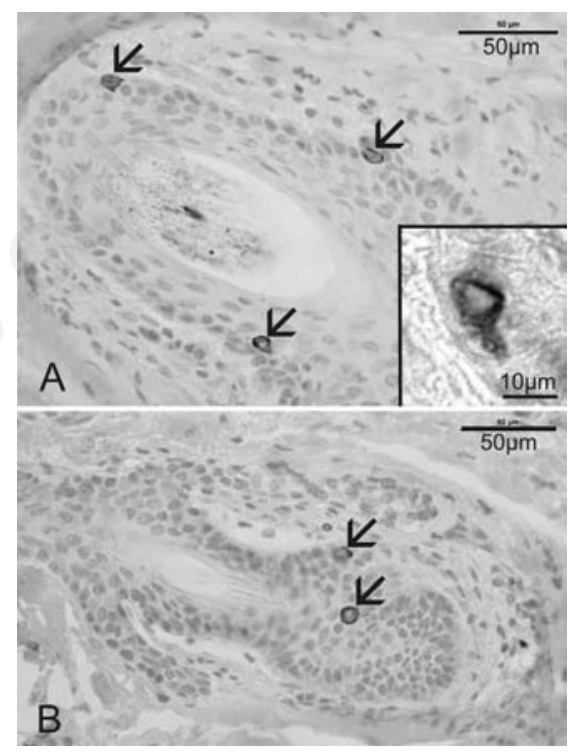

Figure 1. Light microscopic views of $A B C$ stained sections of the upper human eye lid, portion C (see Figure 2). Cytoceratin 20 positive Merkel cells (arrows) are seen in the outer root layer of the ciliae hair follicles (A) and of the small hairs of the cornified epithelium (B). Inset in A: higher magnification of a positively stained Merkel cell showing an unstained nucleus and intensely stained cytoplasm.

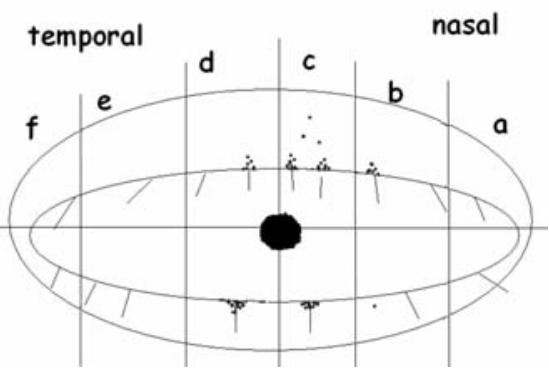

Figure 2. Location of Merkel cells (black dots) in the different portions of the upper and lower eyelids. Note that most cells are located in the middle portions ( $c$ and $d$ ) of both, the upper and lower eyelid. 
the location of Merkel cell carcinoma near the eyelid margin. ${ }^{13,14}$ From this aspect, Merkel cells could serve as a tool for this rare, but highly malignant carcinoma. On the other hand, a report of Merkel cell carcinoma within the conjunctiva, ${ }^{15}$ where no Merkel cells could be detected, might point to a different origin of the carcinoma.

Further studies are necessary to explain the great variation of Merkel cell numbers and to define possible risk factors for malignancy of these cells.

\section{References}

1. Lacour JP, Dubois D, Pisani A, Ortonne JP. Anatomical mapping of Merkel cells in normal human adult epidermis. Br J Dermatol 1991;125:535-42.

2. Halata Z, Grim M, Bauman KI. Friedrich Siegmund Merkel and his "Merkel cell", morphology, development, and physiology: review and new results. Anat Rec 2003;271A:225-39.
3. Moll I, Roessler M, Brandner JM, Eispert AC, Houdek P, Moll R. Human Merkel cellsaspects of cell biology, distribution and functions. Eur J Cell Biol 2005;84:259-71.

4. Munger BL, Halata Z. The sensorineural apparatus of the human eyelid. Am J Anat 1984;170:181-204.

5. Barrett RV, Meyer DR. Eyelid and periocular cutaneous Merkel cell carcinoma (aka. neuroendocrine or trabecular carcinoma). Int Ophthalmol Clin 2012;49:63-75.

6. Chang Y, Moore PS. Merkel cell carcinoma: a virus-induced human cancer. Annu Rev Pathol 2012;7:123-44.

7. Moll I, Kuhn C, Moll R. Cytokeratin 20 is a general marker of cutaneous Merkel cells while certain neuronal proteins are absent. J Invest Dermatol 1995;104:910-5.

8. Zelenka PS, Arpitha P. Coordinating cell proliferation and migration in the lens and cornea. Semin Cell Dev Biol 2008;19:11324.

9. Narisawa Y, Hashimoto K, Kohda H. Merkel cells of the terminal hair follicle of the adult human scalp. J Invest Dermatol 1994;102:506-10.
10. Moll I. Merkel cell distribution in human hair follicles of the fetal and adult scalp. Cell Tissue Res 1994;277:131-8.

11. Uchigasaki S, Suzuki H, Inoue K. Merkel cells in the vellus hair follicles of human facial skin: a study using confocal laser microscopy. J Dermatol 2004;31:218-22.

12. Björk A, Kugelberg E. The electrical activity of the muscles of the eyes and eyelids in various positions and during movements. Electroencephalogr Clin Neurophysiol 1953;5:595-602.

13. Shields JA, Shields CL. Eyelid, conjunctival, and orbital tumors, 2nd ed. Wolters Kluwer/Lippincott Wiliams \& Wilkins, Philadelphia, PA, USA, 2008.

14. Missotten GS, de Wolff-Rouendaal D, de Keizer RJ. Merkel cell carcinoma of the eyelid review of the literature and report of patients with Merkel cell carcinoma showing spontaneous regression. Ophthal mology 2008;115:195-201.

15. Kase S, Ishijima K, Ishida S, Rao NA. Merkel cell carcinoma of the conjunctiva. Ophthalmology 2010;117:637.e1-2. 